\title{
Bio-literacy perspective: A study of the implementation of outdoor learning-based science process skills in plant
} introduction

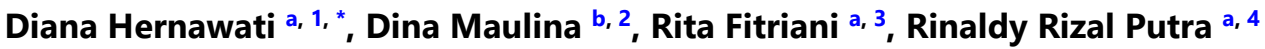 \\ a Biology Education Department, Faculty of Teacher Training and Education, Universitas Siliwangi, \\ Indonesia \\ ${ }^{\mathrm{b}}$ Biology Education Department, Faculty of Teacher Training and Education, Universitas Lampung, \\ Indonesia \\ ${ }^{1}$ hernawatibiologi@unsil.ac.id *, ${ }^{2}$ dina.maulina@fkip.unila.ac.id, ${ }^{3}$ tatairawan12@gmail.com, \\ ${ }^{4}$ rinaldi.rizalputra@unsil.ac.id \\ * Corresponding author
}

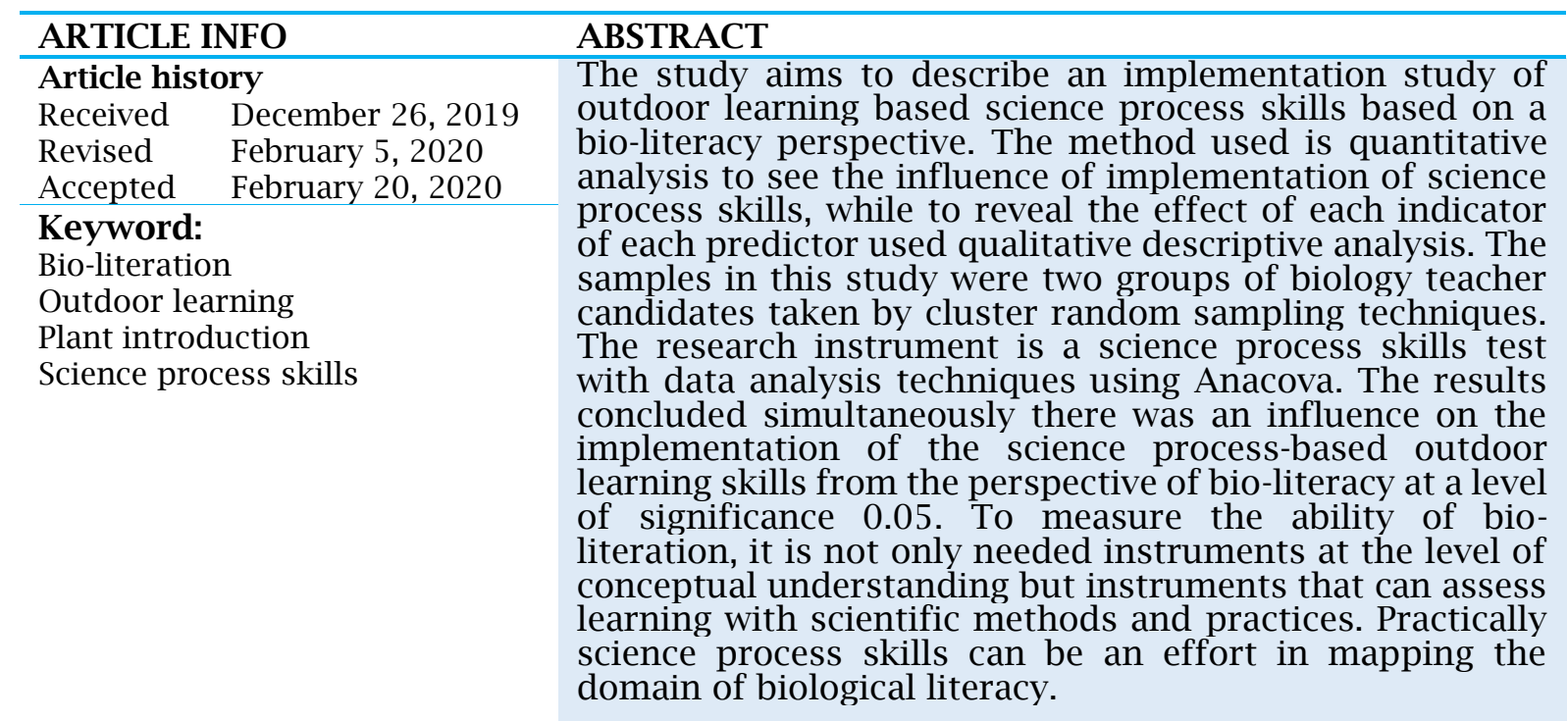

This is an open access article under the CC-BY-SA license.

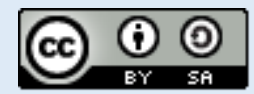

\section{Introduction}

Remarkable scientific progress with many biological discoveries often directly influences daily personal, social, and political decisions. The general public is acutely aware of the rapid progress made in biology. Biological breakthroughs were disseminated both in professional media and mass media. Unbalanced and uncritical publicity can lead to something unrealistic. This tendency is considered as a technological change that is quite comfortable for everyone. However, the results of these biological breakthroughs are still few or even rarely associated with daily behavior.

One study announced that certain behaviors would increase the chance of certain diseases (Klymkowsky, GarvinDoxas, \& Zeilik, 2003). Behavior when shopping for food gives us a test of our biological intelligence. Every food eaten does not necessarily meet the correct nutritional requirements, although unconsciously there are small amounts of pesticides that are consumed and the body does not directly feel the effects; How to cook food that is usually done is not entirely right on the grounds it does not damage the enzyme; Variations in the genetic 
engineering of fruits and vegetables that are known to not everyone knows will cause danger; Herbal supplements will not necessarily fulfill the promise even though it is tested rigorously. These facts have become a part of everyone's daily life without trying to interpret them.

When these problems are brought into the realm of education both in terms of teaching and learning, everything is considered a problem at all levels of the education system. Many learning systems are more concerned with the level of understanding but do not test their meaning. Many people not only understand scientific terms but can apply the knowledge they learn. It still rarely means any strong understanding by involving fundamental principles. We chose this study as a bio-literacy perspective based on our experience as educators.

Bio-literacy requires the ability to do more than understand, but it requires conceptual understanding, the ability to transfer knowledge and understanding to others. Bio-literacy also trains the ability to think scientifically and recognize relationships from various sciences (Klymkowsky et al., 2003). More precisely, bio-literacy includes knowledge of scientific methods and practices. The method and practice in a learning system is a process. The process that is considered essential and can link with the field of biological studies is the science process skills

Science Process Skills can train activeness in finding facts, building concepts, and being able to face problems both in the learning process and in everyday life (Ambross, Meiring, \& Blignaut, 2014; Molefe \& Stears, 2014). Science Process Skills are mostly learning that emphasizes understanding of concepts by prioritizing thought processes. Science Process Skills teaches how to observe (make observations), measure skills (measure), predict skills (predict), classify skills (classify), reference (express assumptions), and communication skills (Ambross et al., 2014; Durmaz \& Mutlu, 2017). Through these Science Process Skills, students are invited to look at their own thoughts, ask questions, and carry out a series of proof processes to discover the concepts to be learned through direct observation.

A learning activity that offers direct exploration with nature or the community as its transformation media is known as outdoor learning. This teaching system emphasizes more on direct practice, directing students to see firsthand the object of learning and real experience, as well as a place for students to express their creativity. Outdoor learning is also known as outdoor study, outdoor activity, or learning outside the classroom. Some people also call it an outing class, which is an activity that involves nature directly to be a source of learning. On the other hand, the method of teaching outside the classroom is a behavioral effort towards the surrounding environment (Beames \& Ross, 2010; Boric \& Skugor, 2014; Borsos, Patocskai, \& Boric, 2018; Hill, 2013).

The rationalization of the learning system here begins with requiring students as individuals to be able to process information in obtaining facts, concepts, and the development of concepts and values. Each individual tries to develop through various exercises to obtain knowledge based on the phenomena they experience. Departing from the urgency of the problems mentioned above, the purpose of this study is to explain a study of the implementation of outdoor learning-based science process skills viewed from a bioliteracy perspective.

\section{Method}

The research method used is quasiexperimental, with a pretest-posttest control group research design (Creswell \& Guetterman, 2019). This research is a type of quantitative research that sees the implementation of outdoor learning-based science process skills viewed from a bioliteracy perspective. Meanwhile, to uncover the effect of each indicator of each predictor used qualitative descriptive analysis. Indicators of science process skills include: 1) observation (making observations); 2) measuring skills (taking measurements); 3) predictive skills (predict); 4) classifying skills; 5) inference (expressing assumptions); 6) communication skills.

Students studied three topics during this research: namely the primary classification of higher plants, characteristics of higher plants, classification of higher plants based on their usefulness. The experimental class and the classical class all study these three topics. Implementation of outdoor learning methods in the experimental class is done outside the classroom by bringing students to introduce learning resources in the 
outside environment, including observing objects in the campus environment around higher plants, looking for information on the state of the surrounding environment, grouping objects based on their properties. Special nature, and can solve problems that exist in the surrounding environment. While for classical classes, learning is done in the classroom.

The sample used in the form of student teacher candidates consisting of two study groups with each numbering 32 people. Sampling was done by cluster random sampling technique from a population of three study groups of 134 people. The research instrument used 24 item test techniques that were tested by students who were not research samples. The test is given in the form of an essay test according to the indicators put forward by Chabalengula, Mumba, and Mbewe (2012). The questions given consist of 4 items for each indicator. Each answer is seen based on the rubric of the level of bio-literacy ability includes four categories, namely nominal, functional, conceptual and procedural, and multidimensional.

The validity of the test is determined based on the results of trials on 30 students who are not research samples. The feasibility test results of the Science Process
Skills instrument were assisted by using Anates software version 4.0.5 for windows with the Anates program for the description of the problem. The instrument was 24 questions with a significance level of 0.05. The reliability test results with Cronbach's Alpha showed a result of 0.82 , which means that the tests given had a high level of reliability.

The research data were statistically tested using Anacova, which aims to explain the difference between more than two sample groups with a significance level of 5\% (p < 0.5) (Hecke, 2012; Mertler \& Reinhart, 2017). The data obtained firstly tested the analysis prerequisites, including the Kolmogorov-Smirnov Test normality test and homogeneity of variance using the Levene-Test. All data testing was performed using the SPSS Program version 23.0 for windows.

\section{Results and Discussion}

The results of data analysis that have been carried out to explain the implementation of outdoor learning-based science process skills viewed from a bioliteracy perspective are presented in Table 1.

Table 1. Summary of skills analysis of outdoor learning based science

\begin{tabular}{lrrrrr}
\hline & \multicolumn{2}{c}{ Type III Sum of } & & & \\
Source & Squares & Df & Mean Square & \multicolumn{1}{c}{ F } & Sig. \\
\hline Corrected Model & $318.711^{\mathrm{a}}$ & 2 & 159.355 & 10.783 & .000 \\
Intercept & 183.966 & 1 & 183.966 & 12.448 & .001 \\
Pretest_science_process_skills & 184.606 & 1 & 184.606 & 12.491 & .001 \\
Metode & 100.504 & 1 & 100.504 & 6.801 & .011 \\
Error & 886.718 & 60 & 14.779 & & \\
Total & 37782.000 & 63 & & & \\
Corrected Total & 1205.429 & 62 & & & \\
\hline
\end{tabular}

Based on the results of covariate analysis, it can be explained that there is an effect of differences in outdoor learning on science process skills by eliminating the pre-test of Science Process Skills as covariates at a significance of $0.000<0.05$. Simultaneously there is a significant effect of outdoor learning on science process skills at a significance of 0.000 (on the corrected model) with an F value of 10.783 while the significance for the variables of science process skills is $0.011<0.05$.

The results of this study can be a reinforcement when Science Process Skills are always identified with a tool needed for an investigation, critical thinking, and studies that require an explanation from the realm of Science Process Skills. So that Science Process Skills can train the mental and physical abilities needed by students in solving individual and social problems both in science and technology studies (Koksal \& Berberoglu, 2014). the research results explain that Science Process Skills have a good potential impact on academic achievement, enabling students with low reasoning abilities to overcome concepts and principles of learning in science that require high cognitive skills (Huppert, Lomask, \& Lazarowitz, 2002).

The analysis results of each Science Process Skill indicator will be appropriately 
measured when each component can be interpreted clearly. Descriptive analysis results for each indicator of Science Process Skills in the experimental and classical classes or controls presented in Figure 1.

Figure 1 shows that the posttest score of the highest Science Process Skills in the experimental and classical classes was in the classifying indicator of 9.28 and 8.00, respectively, while the lowest scores were in the measuring indicator respectively 1.31 and 1.16. When examined based on the results of the descriptive analysis for each predictor for the experimental class and the classical class is not so much different. However, some things differentiate the treatment of the two classes when we analyze descriptively through the learning process.

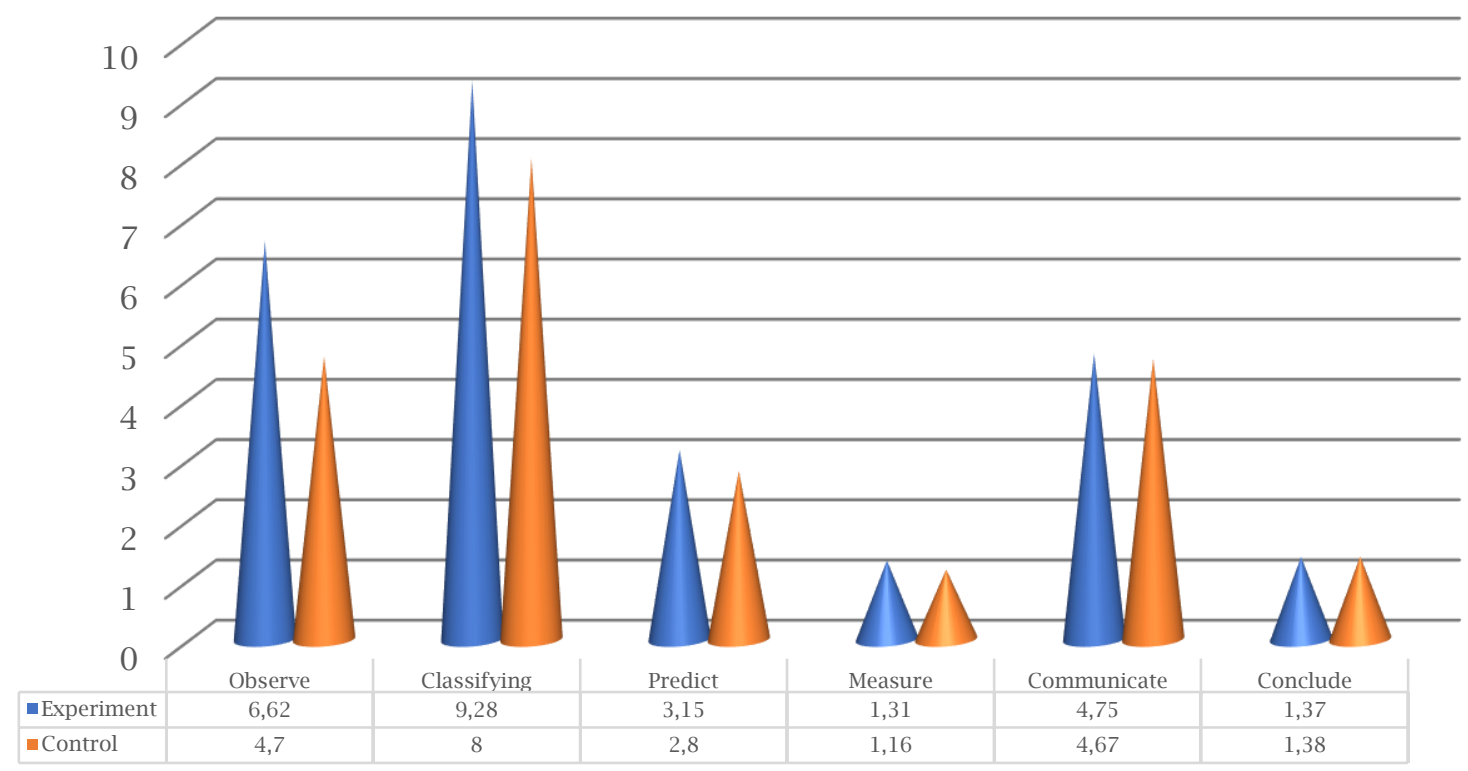

Figure 1. Comparative analysis of science process skill indicators in experimental classes and classical classes

When learning is done outside the classroom, the ability to build interactions with friends is more visible than in classical classrooms. Borsos et al., (2018); Thorburn and Marshall (2014), explained that one of the objectives of learning through outdoor learning is the formation of attitudes and mentality in increasing student awareness, appreciation, and understanding of the surrounding environment.

The interesting thing about observing while learning outside is observing and grouping the types around the campus environment. Students are faced with a number of types of plants and are required to be able to classify plants based on their characteristics and usefulness. High diversity of plant species requires accuracy in observing its characteristics in detail. As in the study of Koksal and Berberoglu (2014) states that better observation of an object will facilitate the classification of the object. On this occasion, students are required to be able to distinguish between woodproducing plants; herbs that function as medicine; food plants; volatile producing plants, dyes, or other chemical compounds and categories of wild plants.

Comparative analysis of the results of exploration in the implementation of outdoor learning in plant material is interpreted as the principle of bio-literacy as presented in Figure 2.

A learning process always has the goal of achieving good results in accordance with learning achievement competencies. Likewise, the achievements of this study must match the achievements of the course. Nevertheless, some things need to be interpreted clearly, not only enough to understand the material that has been planned in a learning plan. This is when students can interpret every process carried out, so they know the importance of integrated bio-literacy in each learning process. 


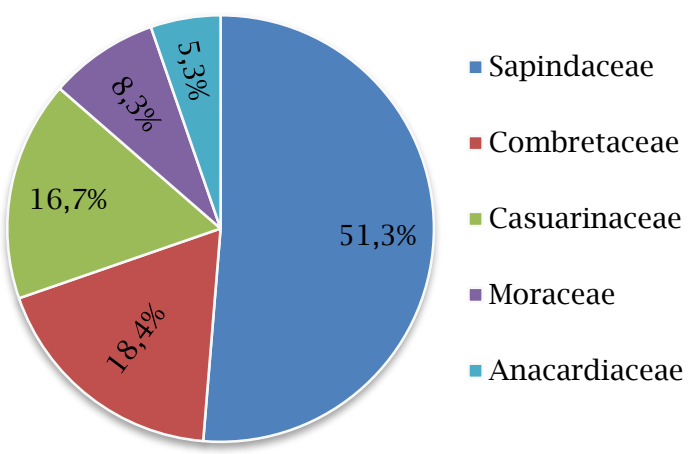

A

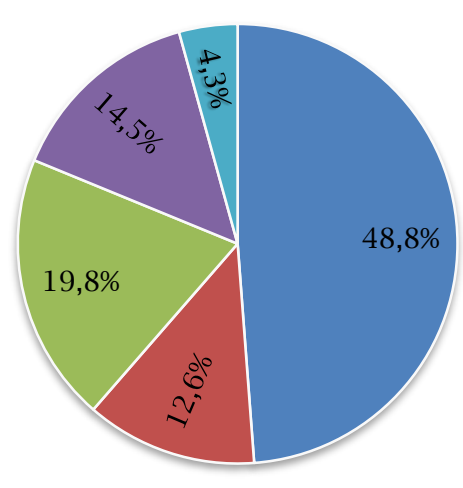

B

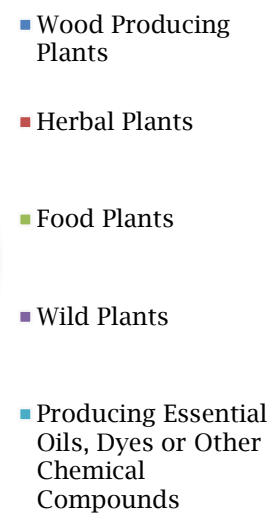

Chemical

Compounds

Figure 2. Grouping by Family (A), Grouping based on benefits (B)

The level of bio-literacy can be known more accurately, so it is necessary to have a reliable instrument to measure students' level of understanding and ability. Students can not only recognize the technical meaning of certain content and concepts but can also apply them correctly. Conceptual understanding that provides the basis for bio-literacy. Literacy is more than knowing individual letters and words, but how to connect to express ideas to describe and explain the phenomena around it (Klymkowsky et al., 2003; Musante, 2011). These skills are needed by students in the process of inquiry to solve problems from a natural phenomenon that is around them. Of course, this is related to the demands of indicators in science process skills (Damopolii, Yohanita, Nurhidaya, \& Murtijani, 2018).

An example is the presentation of Figure 2, which can be interpreted from a bio-literacy perspective. Figure 2A presents the grouping of plants around the campusbased on quantitative families, including Combretaceae, Casuarinaceae, Moraceae, Anacardiaceae. Sapindaceae group dominates plants around the campus, including mahogany tree (Swietenia mahagoni) and teak tree (Tectona grandis). Based on this classification can be interpreted as bio-literacy when it is associated with usefulness in everyday life, or we call it a useful plant. For example, when many woody trees are found, we not only learn about taxonomies based on their morphology but also try to interpret them in different forms.

Figure 2B presents a classification that is interpreted that plants have a use-value for humans. In each of these classifications, we can interpret it. Trees that rise high can carry water from roots to leaves. The reality in everyday life what we can find by taking that philosophy. When people try to avoid chemical drugs by returning to herbal medicines, what is meant is only a function for health. It is as if herbal medicine is the best for avoiding chemical effects on the body. However, other things have never been considered, such as paying attention to the growth of these herbal plants. The importance of this is interpreted as it is feared that the plant will grow and absorb harmful pesticide residues. So the role of herbal medicine will change from useful plants into substances that are harmful to the body.

Useful plants can be interpreted as plants that have benefits for human life, have economic value, and support the livelihood of human life. The many types of plants in the surrounding environment are good opportunities to get to know nature more closely. From here, we learn to know to collect food from nature. Another more scientific word is always referred to as foraging (Carroll, 2018). Foraging is not a form of backwardness, but an integral part of the history of human civilization. Unfortunately, the times have shifted the position of foraging away from our midst. Foraging involves various knowledge disciplines such as botany, nutrition and food, processing, and culinary. Thanks to this amazing knowledge of foraging, the ancestors of the human race survived and survived in the face of natural threats (Carroll, 2018; Mwangi et al., 2012; Ulian, Sacandé, Hudson, \& Mattana, 2017). Through this interpretation, bio-literacy can become part of a millennial century that can combine science, technology, and art. So that foraging techniques that are interpreted as a part of bio-literacy can be integrated in the learning process. 
Thus, bio-literacy includes knowledge of scientific methods and practices. We chose to define bio-literation in this way because our experience as educators has shown that conceptual understanding is the key to meeting more general scientific literacy criteria.

\section{Conclusion}

The study concluded that there was an influence of the implementation of outdoor learning-based science process skills viewed from the perspective of bio-literacy at a significance level of 0.05 . To measure bioliteracy, we must be able to determine the level of individual conceptual understanding so that instruments need more than just memorization tests. In this study, each individual must be able to assess learning meaningfully. Practically PPP can be an attempt to map the biological literacy domain.

\section{Acknowledgement}

We would like to thanks Universitas Siliwangi and Universitas Lampung for its collaboration research. Then we thank for the students of biology teachers for allowing us to carry out the research.

\section{References}

Ambross, J., Meiring, L., \& Blignaut, S. (2014). The implementation and development of science process skills in the natural sciences: A case study of teachers' perceptions. Africa Education Review, 11(3), 459474. https://doi.org/10.1080/18146 627.2014 .934998

Beames, S., \& Ross, H. (2010). Journeys outside the classroom. Journal of Adventure Education and Outdoor Learning, 10(2), 95-109. https://doi.org/10.1080/14729679. 2010.505708

Boric, E., \& Skugor, A. (2014). Achieving students' competencies through research-based outdoor science teaching. Croatian Journal of Education-Hrvatski Casopis Za Odgoj I Obrazovanje, 16(1), 149164. Retrieved from https:// hrcak.srce.hr/120165

Borsos, E., Patocskai, M., \& Boric, E. (2018). Teaching in nature? Naturally!
Journal of Biological Education, 52(4), 429-439. https://doi.org/10. 1080/00219266.2017.1420679

Carroll, A. (2018). 'Leaves and Berries': Agatha christie and the herbal revival. Green Letters, 22(1), 20-30. https://doi.org/10.1080/14688417. 2018.1438303

Chabalengula, V. M., Mumba, F., \& Mbewe, S. (2012). How pre-service teachers' understand and perform science process skills. Eurasia Journal of Mathematics, Science and Technology Education, 8(3), 167176. https://doi.org/10.12973/ eurasia.2012.832a

Creswell, J. W., \& Guetterman, T. C. (2019). Educational research: Planning, conducting, and evaluating quantitative and qualitative research (6th ed.). Retrieved from https://eric.ed.gov/?id=ED594549

Damopolii, I., Yohanita, A. M., Nurhidaya, N., \& Murtijani, M. (2018). Meningkatkan keterampilan proses sains dan hasil belajar siswa melalui pembelajaran berbasis inkuiri. Jurnal Bioedukatika, 6(1), 22-30. https://doi.org/10.26555/bioeduka tika.v6i1.8029

Durmaz, H., \& Mutlu, S. (2017). The effect of an instructional intervention on elementary students' science process skills. Journal of Educational Research, 110(4), 433-445. https://doi.org/10.1080/00220671. 2015.1118003

Hecke, T. Van. (2012). Power study of anova versus Kruskal-Wallis test. Journal of Statistics and Management Systems, 15(2-3), 241-247. https://doi.org/10.1080/09720510. 2012.10701623

Hill, A. (2013). The place of experience and the experience of place: Intersections between sustainability education and outdoor learning. Australian Journal of Environmental Education, 29(1), 18-32. https:// doi.org/10.1017/aee.2013.13

Huppert, J., Lomask, S. M., \& Lazarowitz, R. (2002). Computer simulations in the high school: Students' cognitive stages, science process skills and academic achievement in microbiology. International Journal of Science Education, 24(8), 803-821. 
https://doi.org/10.1080/09500690 110049150

Klymkowsky, M. W., Garvin-Doxas, K., \& Zeilik, M. (2003). Bioliteracy and teaching efficacy: What biologists can learn from physicists. Cell Biology Education, 2(3), 155-161. https://doi.org/10.1187/cbe.03-030014

Koksal, E. A., \& Berberoglu, G. (2014). The effect of guided-inquiry instruction on 6th grade Turkish students' achievement, science process skills, and attitudes toward science. International Journal of Science Education, 36(1), 66-78. https://doi.org/10.1080/09500693. 2012.721942

Mertler, C. A., \& Reinhart, R. V. (2017). Advanced and multivariate staistical methods practical application and interpretation (6th ed.). Retrieved from https://books.google.co.id/

Molefe, L., \& Stears, M. (2014). Rhetoric and reality: Science teacher educators' views and practice regarding science process skills. African Journal of Research in Mathematics, Science and Technology Education, 18(3), 219-230. https://doi.org/10.1080/ 10288457.2014 .942961
Musante, S. (2011). Upgrading undergraduate biology education. BioScience, 61(7), 512-513. https://doi.org/10.1525/bio.2011.6 1.7.5

Mwangi, D., Kasina, M., Nderitu, J., Hagen, M., Gikungu, M., \& Kraemer, M. (2012). Diversity and abundance of native bees foraging on hedgerow plants in the Kakamega farmlands , western Kenya. Journal of Apicultural Research, 51(4), 298305. https://doi.org/10.3896/IBRA. 1.51.4.02

Thorburn, M., \& Marshall, A. (2014). Cultivating lived-body consciousness: Enhancing cognition and emotion through outdoor learning. Journal of Pedagogy, 5(1), 115-132. https://doi.org/10.2478/ jped-2014-0006

Ulian, T., Sacandé, M., Hudson, A., \& Mattana, E. (2017). Conservation of indigenous plants to support community livelihoods: the MGU Useful Plants Project. Journal of Environmental Planning and Management, 60(4), 668-683. https://doi.org/10.1080/09640568. 2016.1166101 